\title{
Low concentrations of clarithromycin upregulate cellular antioxidant enzymes and phosphorylation of extracellular signal- regulated kinase in human small airway epithelial cells
}

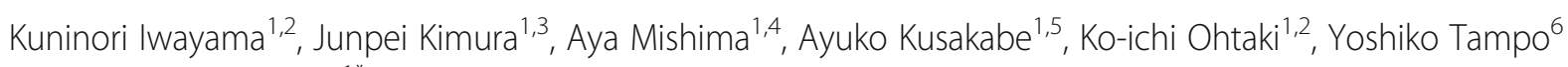
and Nobumasa Hayase ${ }^{1 *}$

\begin{abstract}
Background: It is well known that low-dose, long-term macrolide therapy is effective against chronic inflammatory airway diseases. Oxidative stress is considered to be a key pathogenesis factor in those diseases. However, the mechanism of action of low-dose, long-term macrolide therapy remains unclear. We have reported that clarithromycin (CAM), which is a representative macrolide antibiotic, could inhibit hydrogen peroxide $\left(\mathrm{H}_{2} \mathrm{O}_{2}\right)$ induced reduction of the glutathione (GSH)/glutathione disulfide (GSSG) ratio in human small airway epithelial cells (SAECS), via the maintenance of GSH levels through an effect on $\gamma$-glutamylcysteine synthetase ( $\gamma$-GCS) expression. In this study, we examined the influence of CAM against $\mathrm{H}_{2} \mathrm{O}_{2}$-induced activities of cellular antioxidant enzymes and phosphorylated extracellular signal regulatory kinase (p-ERK) using SAECs, the main cells involved in chronic airway inflammatory diseases.
\end{abstract}

Methods: SAECs were pretreated with CAM $(1,5$, and $10 \mu M)$ for $72 \mathrm{~h}$, and subsequently exposed to $\mathrm{H}_{2} \mathrm{O}_{2}$ $(100 \mu \mathrm{M})$ for $0.5-2 \mathrm{~h}$. Levels of GSH and GSSG, and activities of glutathione peroxidase (GPx)-1, glutathione reductase (GR), superoxide dismutase (SOD), catalase (CAT), heme oxygenase (HO)-1 and p-ERK were assayed. mRNA expressions of GPx-1 and HO-1 were measured using the real-time reverse transcription polymerase chain reaction (RT-PCR). Tukey's multiple comparison test was used for analysis of statistical significance.

Results: Pretreatment with low-dose (1 and $5 \mu \mathrm{M}$ ) CAM for $72 \mathrm{~h}$ inhibited $\mathrm{H}_{2} \mathrm{O}_{2}$-induced reductions of GPx-1, GR, SOD, CAT and HO-1 activities, and mRNA expressions of GPX-1 and HO-1, and improved the GSH/GSSG ratio. However, these alterations were not observed after pretreatment with high-dose $(10 \mu \mathrm{M}) \mathrm{CAM}$, which suppressed phosphorylation of cell proliferation-associated ERK to cause a significant $(p<0.01)$ decrease in cell viability.

(Continued on next page)

\footnotetext{
* Correspondence: nh2767@hus.ac.jp

1Department of Pharmacology and Therapeutics, Hokkaido Pharmaceutical University School of Pharmacy, 7-15-4-1 Maeda, Teine, Sapporo, Hokkaido 006-8590, Japan

Full list of author information is available at the end of the article
}

(c) The Author(s). 2018 Open Access This article is distributed under the terms of the Creative Commons Attribution 4.0 International License (http://creativecommons.org/licenses/by/4.0/), which permits unrestricted use, distribution, and reproduction in any medium, provided you give appropriate credit to the original author(s) and the source, provide a link to the Creative Commons license, and indicate if changes were made. The Creative Commons Public Domain Dedication waiver (http://creativecommons.org/publicdomain/zero/1.0/) applies to the data made available in this article, unless otherwise stated. 


\begin{abstract}
(Continued from previous page)
Conclusions: CAM is efficacious against deterioration of cellular antioxidant enzyme activity caused by oxidative stress under low-dose, long-term treatment conditions. On the other hand, pretreatment with high-dose CAM suppressed phosphorylation of cell proliferation-associated ERK and decreased cell viability. The present study may provide additional evidence as to why low-dose, long-term administration of macrolides is effective for treating chronic inflammatory airway diseases.
\end{abstract}

Keywords: Clarithromycin, Anti-inflammatory effect, Low-dose, Long-term treatment, Human small airway epithelial cells, Oxidant/antioxidant balance, Cellular antioxidant enzyme, Extracellular signal regulatory kinase

\section{Background}

Macrolides such as clarithromycin (CAM) have been reported to be effective for the treatment of chronic inflammatory airway diseases at low doses and with long-term administration [1-5]. The effectiveness of macrolides in treating inflammatory airway diseases has been thought to be due to their immunomodulatory effects rather than their direct antimicrobial activity. For instance, both CAM and erythromycin (EM) inhibit the production of inflammatory cytokines, such as interleukin (IL)-6 and IL-8, inhibit the release of soluble intracellular adhesion molecule-1 from airway epithelial cells, and decrease airway neutrophil accumulation $[6,7]$. However, there is limited data concerning the potential benefits of low-dose, long-term application of CAM in a variety of chronic inflammatory airway diseases.

Recently, we demonstrated that long-term pretreatment with low-dose CAM is effective for suppressing the expression of transcription factors involved in inflammatory cytokine production in response to hydrogen peroxide $\left(\mathrm{H}_{2} \mathrm{O}_{2}\right)$-induced cytotoxicity in human small airway epithelial cells (SAECs) [8]. For example, pre-treatment with 1 or $5 \mu \mathrm{M}$ CAM, but not with $10 \mu \mathrm{M}$ CAM, for $72 \mathrm{~h}$ prior to $\mathrm{H}_{2} \mathrm{O}_{2}$ treatment significantly decreased $\mathrm{H}_{2} \mathrm{O}_{2}$-induced IL-8 protein release (see Additional file 1 ). $\mathrm{H}_{2} \mathrm{O}_{2}$ is one of the reactive oxygen species (ROS), and was employed in this study to alter the oxidant/antioxidant balance in living cells. In chronic inflammatory respiratory diseases such as chronic obstructive pulmonary disease (COPD) [9], bronchial asthma [10], bronchiectasis [11] and cystic fibrosis [12], the $\mathrm{H}_{2} \mathrm{O}_{2}$ concentration in the exhaled breath has been reported to be several times higher than healthy subjects. Therefore, in these pathological conditions, it may be considered that the oxidant/antioxidant balance in bronchial epithelial cells is seriously impaired. Indeed, our previous study demonstrated that the intracellular glutathione (GSH)/glutathione disulfide (GSSG) ratio is strongly reduced when SAECs are treated with $\mathrm{H}_{2} \mathrm{O}_{2}$ $(100 \mu \mathrm{M})$ [8]. However, long-term $(72 \mathrm{~h})$ pretreatment with low-dose $(1$ or $5 \mu \mathrm{M})$ CAM significantly improved this ratio to maintain cell viability (see Additional file 2). In contrast, this alteration was not observed after pretreatment with high-dose $(10 \mu \mathrm{M})$ or short-term $(24$ and $48 \mathrm{~h})$
CAM. Thus, the effects of CAM on the oxidant/antioxidant balance in cells depend on the concentration and pretreatment time. On the other hand, there is a defensive pathway called the ROS elimination system that is known to suppress the concentration of ROS in cells [13] (Scheme 1). Namely, superoxide anion radicals produced in vivo by inflammatory substances is directly converted to $\mathrm{H}_{2} \mathrm{O}_{2}$ by superoxide dismutase (SOD). $\mathrm{H}_{2} \mathrm{O}_{2}$ is decomposed into water and oxygen by catalase (CAT) and glutathione peroxidase (GPx)-1, which oxidizes GSH to GSSG. Alternatively, GSSG is reduced to GSH by glutathione reductase (GR) and NADPH. Furthermore, a part of $\mathrm{H}_{2} \mathrm{O}_{2}$ undergoes the Fenton reaction with ferrous iron, and is converted to hydroxyl radical, which has the highest oxidizing activity. Ferrous iron is produced by the degradation of heme, and this reaction is catalyzed by heme oxidase (HO)-1. Moreover, HO-1 potentially generates a significant amount of $\mathrm{H}_{2} \mathrm{O}_{2}$, which is a source of hydroxyl radical. CAM may enhance the system for ROS elimination in cells. However, there are no reports describing the direct effects of CAM on activities concerning ROS elimination enzymes.

In addition to the above data, it has been observed that $\mathrm{H}_{2} \mathrm{O}_{2}$ activates the mitogen activated protein kinase (MAPK) pathway [14-16]. This pathway consists mainly of three types of cascade, extracellular signal regulatory kinase (ERK), c-jun N-terminal kinase (JNK) and p38 cascades. When the MAPK (ERK, JNK and p38) pathway is stimulated by oxidative stress, each of the cascades is activated by phosphorylation to exert a different physiological action [17]. Among these cascades, ERK phosphorylation mediates cell proliferation in bronchial epithelial cells $[18,19]$. Therefore, it may be considered that inhibition of ERK phosphorylation causes cell death in bronchial epithelial cells. The cytoprotective action of CAM may be associated with the increase in phosphorylation against $\mathrm{H}_{2} \mathrm{O}_{2}$-induced cell dysfunction. However, there are no reports describing the direct effects of CAM on ERK phosphorylation induced by $\mathrm{H}_{2} \mathrm{O}_{2}$.

In this study, we examined the effect of CAM on $\mathrm{H}_{2} \mathrm{O}_{2}$-induced expression of GPx-1, GR, SOD, HO-1 and CAT in SAECs under the same conditions previously demonstrated to show the cytoprotective effect of 


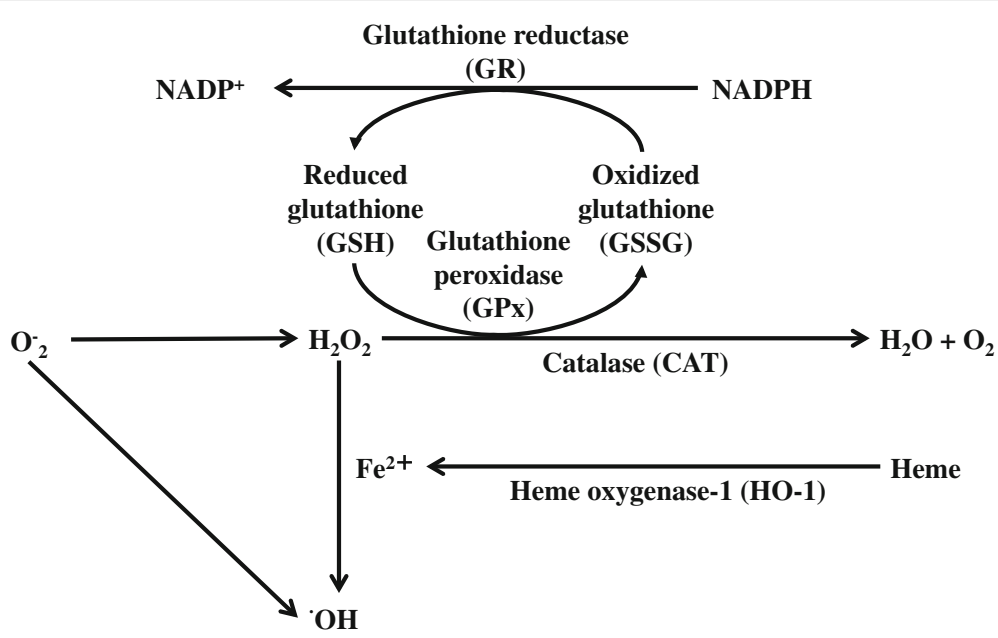

Scheme 1 Cellular antioxidant enzymes involved in the ROS elimination system

CAM [8]. In addition, we investigated the effect of CAM on $\mathrm{H}_{2} \mathrm{O}_{2}$-induced ERK phosphorylation in SAECs.

\section{Methods \\ Materials}

CAM, $\mathrm{H}_{2} \mathrm{O}_{2}$ (30\%), dimethylsulfoxide (DMSO), $\mathrm{NaN}_{3}$, the WST-8 (2-(2-methoxy-4-nitrophenyl)-3-(4-nitrophenyl)-5-(2,4-disulfophenyl)-2H-tetrazolium) assay system, and 5,5'-dithiobis(2-nitrobenzoic acid) (DTNB) were purchased from Wako Pure Chemical Industries, Ltd. (Osaka, Japan). Mouse anti-phosphorylated ERK and anti-total ERK monoclonal antibodies, and U0126 were from Cell Signaling Technology (Tokyo, Japan). GSH, GSSG, EDTA and mouse anti- $\beta$-actin monoclonal antibody were from Sigma-Aldrich Chemical Co. (St. Louis, MO, USA). GR (from yeast) and NADPH were from Oriental Yeast Co., Ltd. (Tokyo, Japan). Dulbecco's phosphate-buffered saline (DPBS) and phosphate-buffered saline (PBS) at $\mathrm{pH} 7.4$ were from Gibco BRL (Grand Island, NY, USA). Triton-X was from IBI Scientific (Kapp Court Peosta, IA, USA). All other chemicals used were of reagent grade.

\section{Cell culture and treatments}

Cell culture and treatments were according to methods described previously [8]. Briefly, SAECs, cells of a normal human small airway epithelial cell line, and SAEC culture media were purchased from Lonza (Walkersville, MD, USA). Cells were seeded in $75-\mathrm{cm}^{2}$ filter vent flasks (Corning, NY, USA) and grown to $80 \%$ confluence $\left(3 \times 10^{6}\right.$ cells/well $)$ for each experimental condition, at $37{ }^{\circ} \mathrm{C}$ in a humidified atmosphere of $5 \%$ $\mathrm{CO}_{2}$ and $95 \%$ air. The culture medium was changed on day 1 and subsequently every 2 days. Cells were passaged by trypsinization, and cultures between passages 3 and 9 were used for all experiments. Cells were cultured in the presence or absence of CAM $(1,5$ or $10 \mu \mathrm{M})$ for $72 \mathrm{~h}$ and then stimulated with $\mathrm{H}_{2} \mathrm{O}_{2}(100 \mu \mathrm{M})$ for an additional $0.5-2 \mathrm{~h}$. Neither $1,5 \mu \mathrm{M}$ (low) or $10 \mu \mathrm{M}$ (high) CAM nor $100 \mu \mathrm{M} \mathrm{H}_{2} \mathrm{O}_{2}$ affected SAEC proliferation or viability (see Additional files 3 and 4). Based on our previous study [8], the long-term treatment with CAM was set at $72 \mathrm{~h}$. Pretreatments with CAM were carried out with a different set of cells for each concentration. In addition, cell stimulation with $\mathrm{H}_{2} \mathrm{O}_{2}$ was performed as follows in order to determine the point at which the effect of $\mathrm{H}_{2} \mathrm{O}_{2}$ treatment was the strongest. For stimulation of the cells with $\mathrm{H}_{2} \mathrm{O}_{2}$, the medium was changed to small airway basal medium (SABM) containing no supplements, since bovine pituitary extract and serum may include antioxidants, chelators of transition metal ions, and high-density lipoproteins [20]. CAM was dissolved in DMSO at a final concentration of $10 \mathrm{mM}$ and then diluted with distilled water or culture medium to the desired concentrations. The final concentration of DMSO was less than 0.1\%. CAM solution used for experiments was prepared immediately before use.

\section{GPx-1 activity}

GPx-1 activity was measured using NADPH consumption as an index [21]. SAECs $\left(5 \times 10^{5}\right.$ cells/well) on 12 -well plates were pretreated with CAM $(1,5$ or $10 \mu \mathrm{M})$ for $72 \mathrm{~h}$ and then stimulated with $\mathrm{H}_{2} \mathrm{O}_{2}(100 \mu \mathrm{M})$ for 1.5 h. Cells were washed with DPBS and then solubilized with PBS $(220 \mu \mathrm{L})$ containing $0.1 \%$ Triton-X and incubated at $-20{ }^{\circ} \mathrm{C}$ for $10 \mathrm{~min}$. After incubation, the cell lysate was centrifuged at $10,000 \times g$ for $10 \mathrm{~min}$ at $4{ }^{\circ} \mathrm{C}$. GPx-1 activity in the cell lysate was measured spectrophotometrically using a method based on the decrease in absorbance at $340 \mathrm{~nm}$ due to the oxidation of NADPH in the presence of GSH and GR. This assay system consisted of $50 \mathrm{mM}$ PBS (pH 7.6, $150 \mu \mathrm{L}$ ) containing $1 \mathrm{mM} \mathrm{NaN}_{3}$, 
$1 \mathrm{mM}$ EDTA, $1 \mathrm{mM} \mathrm{GSH}, 0.2 \mathrm{mM}$ NADPH, $1 \mathrm{U} / \mathrm{mL}$ GR, sample $(50 \mu \mathrm{L})$, to which $\mathrm{H}_{2} \mathrm{O}_{2}(250 \mu \mathrm{M})$ was added to start the reaction. GPx-1 activities were calculated using the molar extinction coefficient value at $340 \mathrm{~nm}$ of $6.22 \mathrm{mM}^{-1} \mathrm{~cm}^{-1}$, and are expressed as a ratio (\%) to changes in $\mathrm{H}_{2} \mathrm{O}_{2}$ untreated cells.

\section{Real-time RT-PCR for GPx-1 and HO-1 mRNAs}

The mRNA expressions of GPx-1 and HO-1 were measured by quantitative RT-PCR analysis. Briefly, SAECs $\left(10^{6}\right.$ cells/well $)$ in 6 -well plates were pretreated with CAM $(1,5$ or $10 \mu \mathrm{M})$ for $72 \mathrm{~h}$ and then stimulated with $\mathrm{H}_{2} \mathrm{O}_{2}(100 \mu \mathrm{M})$ for $1 \mathrm{~h}$. Total RNA was obtained using a PureLink RNA Mini Kit (Life Technologies Corp., Carlsbad, CA, USA) following the manufacturer's instructions and quantified by absorbance measurement at $260 \mathrm{~nm}$. RNA $(2 \mu \mathrm{g})$ was reverse transcribed into complementary deoxyribonucleic acid (cDNA) using a SuperScript VILO cDNA Synthesis Kit following the manufacturer's instructions (Invitrogen, Carlsbad, CA, USA). TaqMan polymerase chain reaction (PCR) primers and probes for GPx-1 or $\mathrm{HO}-1$ and for glyceraldehyde-3-phosphate dehydrogenase (GAPDH) as the internal standard gene were purchased from Applied Biosystems (Foster City, CA, USA). TaqMan PCR was performed with $1 \mu \mathrm{L}$ of sample cDNA in a $20-\mu \mathrm{L}$ reaction mixture containing TaqMan gene master mix and TaqMan gene expression assays for GPx-1 and HO-1. Amplification was performed using the 7500 Real Time Reverse Transcription-PCR System (Applied Biosystems). The PCR thermal protocol consisted of $50{ }^{\circ} \mathrm{C}$ for $2 \mathrm{~min}$ and $95{ }^{\circ} \mathrm{C}$ for $10 \mathrm{~min}$, followed by 40 -cycle amplification at $95{ }^{\circ} \mathrm{C}$ for $15 \mathrm{~s}$ and $60{ }^{\circ} \mathrm{C}$ for $1 \mathrm{~min}$. Relative quantification of gene expression was performed using the comparative threshold method. Changes in mRNA expression were calculated after normalizing to GAPDH, and are expressed as a ratio to changes in $\mathrm{H}_{2} \mathrm{O}_{2}$ untreated cells.

\section{GR activity}

GR activity was also measured using NADPH consumption as an index [21]. Cell pretreatment with CAM, $\mathrm{H}_{2} \mathrm{O}_{2}$ treatment, and sample preparation were carried out in the same manner as for measurement of GPx-1 activity. GR activity in the cell lysate was measured spectrophotometrically using a method based on the decrease in absorbance at $340 \mathrm{~nm}$ due to the oxidation of NADPH in the presence of GSSG. This assay system consisted of $50 \mathrm{mM}$ PBS $(\mathrm{pH} 7.6,250 \mu \mathrm{L})$ containing $2 \mathrm{mM}$ EDTA, $1 \mathrm{mM}$ GSSG, $0.1 \mathrm{mM} \mathrm{NADPH}$ and sample $(100 \mu \mathrm{L})$. GR activities were calculated using the molar extinction coefficient value at $340 \mathrm{~nm}$ of $6.22 \mathrm{mM}^{-1} \mathrm{~cm}^{-1}$, and are expressed as a ratio (\%) to changes in $\mathrm{H}_{2} \mathrm{O}_{2}$ untreated cells.

\section{CAT activity}

CAT activity was measured using a catalase assay kit (Cayman Chemical Co., Ann Arbor, MI, USA) according to the manufacturer's instructions. Cell pretreatment with $\mathrm{CAM}, \mathrm{H}_{2} \mathrm{O}_{2}$ treatment, and sample preparation were carried out in the same manner as for measurement of GPx-1 activity. This assay system consisted of $100 \mathrm{mM}$ PBS (pH 7.0, $100 \mu \mathrm{L})$, methanol $(30 \mu \mathrm{L})$ and sample $(20 \mu \mathrm{L})$. The reaction was started by adding $35 \mu \mathrm{M} \mathrm{H}_{2} \mathrm{O}_{2}$ and the reaction mixture was incubated for $20 \mathrm{~min}$ at room temperature. After incubation, $10 \mathrm{M}$ potassium hydroxide and chromogen were added to the mixture. After further incubation for $10 \mathrm{~min}$, potassium periodate was added and incubated for $5 \mathrm{~min}$ at room temperature before reading the absorbance at $540 \mathrm{~nm}$ using a plate reader (Bio-Rad, Hercules, CA, USA). CAT activities were calculated using the equation obtained from the linear regression of the standard curve. Data are expressed as a ratio (\%) to changes in $\mathrm{H}_{2} \mathrm{O}_{2}$ untreated cells.

\section{SOD activity}

The SOD assay was performed using an SOD assay kit-WST (Dojindo Laboratories, Kumamoto, Japan) according to the manufacturer's instructions. Cell pretreatment with CAM, $\mathrm{H}_{2} \mathrm{O}_{2}$ treatment, and sample preparation were carried out in the same manner as for measurement of GPx-1 activity. This assay system, based on the NBT method utilizing the tetrazolium salt reduction reaction, consisted of a sample $(20 \mu \mathrm{L})$, the provided WST working solution $(200 \mu \mathrm{L})$ and an enzyme working solution $(20 \mu \mathrm{L})$. This mixture was incubated for $20 \mathrm{~min}$ at room temperature and absorbance was then measured at $450 \mathrm{~nm}$. The SOD activities were calculated using the equation obtained from the regression analysis of the standard curve. Data are expressed as a ratio (\%) to changes in $\mathrm{H}_{2} \mathrm{O}_{2}$ untreated cells.

\section{Western blot analysis for HO-1 protein and ERK phosphorylation}

Phosphorylated ERK (p-ERK), total ERK (t-ERK) and HO-1 protein levels were analyzed by Western blot analysis. SAECs $\left(10^{6}\right.$ cells/well $)$ on 6 -cm dishes were pretreated with CAM $(1,5$ or $10 \mu \mathrm{M})$ for $72 \mathrm{~h}$ and then treated with $\mathrm{H}_{2} \mathrm{O}_{2}$ for $0.5 \mathrm{~h}$. Cells were washed with DPBS, and collected using fresh DPBS and a cell scraper. After centrifugation at $2000 \times g$ for $10 \mathrm{~min}, 50 \mu \mathrm{L}$ of radioimmunoprecipitation assay (RIPA) buffer (Pierce, Rockford, IL, USA) containing $1 \mathrm{M}$ vanadate and protease inhibitors was added and then cell pellets were sonicated three times for $10 \mathrm{~s}$ each. The lysates were centrifuged at $12000 \times \mathrm{g}$ for $10 \mathrm{~min}$, and a $10-\mu \mathrm{g}$ aliquot of total protein in supernatant was resuspended in the same amount of sample buffer (Laemmli sample buffer 
containing $0.5 \mathrm{mM}$ 2-mercaptoethanol) and boiled for 5 min. After refrigeration, the sample was separated using $12 \%$ sodium dodecyl sulfate polyacrylamide gel electrophoresis (SDS-PAGE). Next, the gel was electrotransferred onto a nitrocellulose membrane (Bio-Rad). Membranes were blocked in 5\% nonfat dry milk in Tris-buffered solution containing $0.1 \%$ Tween 20 (TBST) at room temperature for $2 \mathrm{~h}$. The membrane was incubated with a 1:2000 dilution of primary antibody for $\mathrm{p}$-ERK, $\mathrm{t}$-ERK or $\beta$-actin with a 1:1000 dilution of horseradish peroxidase-conjugated secondary antibody. Signals were detected as the intensity of chemiluminescence using an ECL Plus Western Blotting Detection Kit (GE Healthcare, Buckinghamshire, UK). p-ERK or HO-1 levels were normalized to constitutive expression of total protein or $\beta$-actin, respectively, and are expressed as $\mathrm{p}$-ERK/t-ERK or $\mathrm{HO}-1 / \beta$-actin calculated as the scan unit ratio (\%) \pm standard deviation (SD) of three experiments using imageJ software (NIH, Bethesda, MD, USA).

\section{Cell viability}

Cell viability was assessed using the cell counting kit-8 assay, WST-8. SAECs $\left(3 \times 10^{4}\right.$ cells/well $)$ on 96-well plates were pretreated with U0126 $(10 \mu \mathrm{M})$ for $0.5 \mathrm{~h}$ and then stimulated with $\mathrm{H}_{2} \mathrm{O}_{2}(100 \mu \mathrm{M})$ for $3 \mathrm{~h}$. After the treatment, the medium of SAECs was changed to basal medium (SABM) containing 10\% WST-8 solution and the cells were incubated at $37{ }^{\circ} \mathrm{C}$ for $2 \mathrm{~h}$. Viable cells convert the WST-8 solution to an orange-colored formazan product with an absorbance at $450 \mathrm{~nm}$. The optical density of the culture medium was measured at $450 \mathrm{~nm}$ with a spectrophotometric microliter plate reader (Bio-Rad). The cell proliferation and viability are expressed as the ratio (\%) of surviving cells to $\mathrm{H}_{2} \mathrm{O}_{2}$ untreated cells. The morphology of SAECs was evaluated visually throughout the course of the experiments.

\section{Other procedures}

Intracellular GSH and GSSG levels were measured by spectrophotometric methods as described previously [8]. Protein concentrations were determined using the Bradford method with bovine serum albumin as the standard.

\section{Statistical analysis}

All data are expressed as means \pm SD. Statistical analysis was performed using one-way analysis of variance (ANOVA), and differences, which were estimated by Tukey's multiple comparison test after the Goodness of fit test and Bartlett's test, were considered to be statistically significant at $p<0.05$.

\section{Results \\ Effects of CAM pretreatment on the $\mathrm{H}_{2} \mathrm{O}_{2}$-induced GSH/GSSG ratio in SAECs}

SAECs were pretreated with CAM at 1,5 or $10 \mu \mathrm{M}$ for 72 h. CAM at those concentrations had no effect on cell viability (see Additional file 3). Although $\mathrm{H}_{2} \mathrm{O}_{2}$ treatment at $100 \mu \mathrm{M}$ did not affect the viability of SAECs (see Additional file 4), incubation with $\mathrm{H}_{2} \mathrm{O}_{2}(100 \mu \mathrm{M})$ for $2 \mathrm{~h}$ significantly decreased the GSH/GSSG ratio compared to untreated cells (Fig. $1, p<0.01$ ). Pretreatment with a low concentration $(1$ or $5 \mu \mathrm{M})$, but not a high concentration $(10 \mu \mathrm{M})$, of CAM for $72 \mathrm{~h}$ significantly increased this ratio in $\mathrm{H}_{2} \mathrm{O}_{2}$-treated cells $(p<0.01$ vs. $\mathrm{H}_{2} \mathrm{O}_{2}$ treatment alone). There was a significant difference in the $\mathrm{H}_{2} \mathrm{O}_{2}$-induced GSH/GSSG ratio between the low- and high-concentration CAM groups $(p<0.01)$.

\section{Effects of CAM pretreatment on GPx-1, GR activities and GPX-1 mRNA expression in $\mathrm{H}_{2} \mathrm{O}_{2}$-treated cells}

GPx-1 and GR activities were significantly decreased by $\mathrm{H}_{2} \mathrm{O}_{2}$ treatment $(100 \mu \mathrm{M})$ for $1.5 \mathrm{~h}$ compared with untreated cells (Figs. 2a and 3; $p<0.05$ and $p<0.01$, respectively). In contrast, pretreatment with a low concentration of CAM (1 or $5 \mu \mathrm{M}$ ) for $72 \mathrm{~h}$ significantly increased these activities compared with $\mathrm{H}_{2} \mathrm{O}_{2}$ treatment alone $(p<0.01)$. However, pretreatment with a high concentration of CAM $(10 \mu \mathrm{M})$ for $72 \mathrm{~h}$ had no influence on both activities decreased by $\mathrm{H}_{2} \mathrm{O}_{2}$ treatment. Similar to these changes in GPx-1 and GR activities, GPx-1 mRNA expression was also significantly decreased by exposure to $\mathrm{H}_{2} \mathrm{O}_{2}$ for $1 \mathrm{~h}$ (Fig. $2 \mathrm{~b} ; p<0.05$ ). In contrast, a low concentration of CAM (1 or $5 \mu \mathrm{M})$ increased this expression compared with $\mathrm{H}_{2} \mathrm{O}_{2}$ treatment alone $(p<0.01$ or $p<0.05$, respectively). However, a high concentration of CAM $(10 \mu \mathrm{M})$ had no effect on the expression. Similar to the effect of CAM on the $\mathrm{H}_{2} \mathrm{O}_{2}$-induced GSH/GSSG ratio, there were also significant differences in the $\mathrm{H}_{2} \mathrm{O}_{2}$-induced GPx-1, GR activities and GPx-1 mRNA expression between the low- and high-concentration CAM groups $(p<0.01)$.

\section{Effects of CAM pretreatment on CAT and SOD activities in $\mathrm{H}_{2} \mathrm{O}_{2}$-treated cells}

We next examined whether CAM could alter CAT and SOD protein levels in SAECs after treatment with $\mathrm{H}_{2} \mathrm{O}_{2}$ $(100 \mu \mathrm{M})$ for $1.5 \mathrm{~h}$. As shown in Figs. 4 and 5, both CAT and SOD activities were decreased in $\mathrm{H}_{2} \mathrm{O}_{2}$-treated cells. Nevertheless, pretreatment with a low concentration of CAM ( 1 or $5 \mu \mathrm{M})$ for $72 \mathrm{~h}$ significantly increased those activities compared with $\mathrm{H}_{2} \mathrm{O}_{2}$ treatment alone $(p<0.01)$. On the other hand, pretreatment with a high concentration of CAM $(10 \mu \mathrm{M})$ for $72 \mathrm{~h}$ had no influence on both activities decreased by $\mathrm{H}_{2} \mathrm{O}_{2}$ treatment. There were also significant differences in the 
$\square$ : control, $\mathbf{\square}: 100 \mu \mathrm{M} \mathrm{H}_{2} \mathrm{O}_{2}$ alone, $\mathbb{Z}: 100 \mu \mathrm{M} \mathrm{H}_{2} \mathrm{O}_{2}+1 \mu \mathrm{M}$ CAM,

曰: $100 \mu \mathrm{M} \mathrm{H}_{2} \mathrm{O}_{2}+5 \mu \mathrm{M} \mathrm{CAM}, \bigotimes: 100 \mu \mathrm{M} \mathrm{H}_{2} \mathrm{O}_{2}+10 \mu \mathrm{M} \mathrm{CAM}$

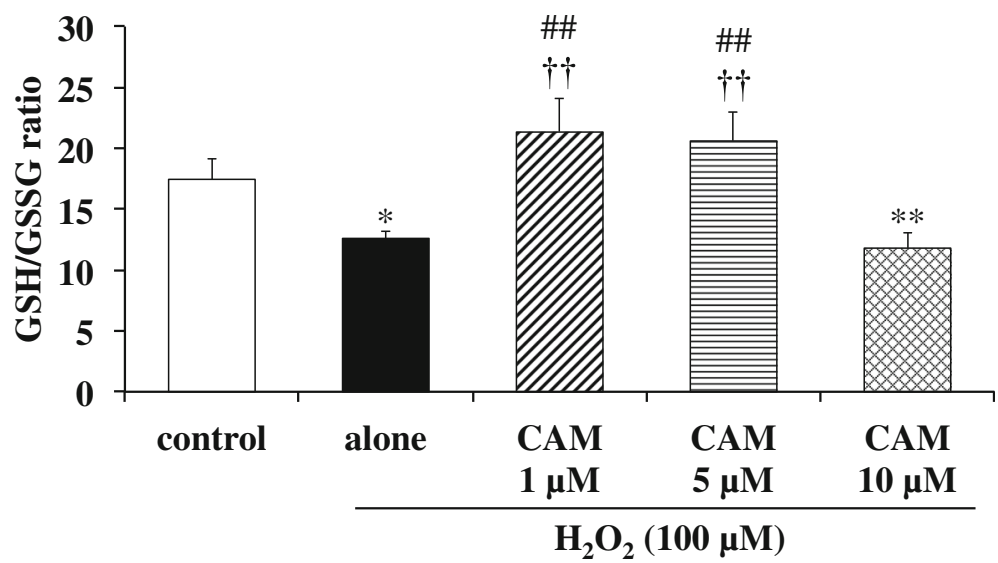

Fig. 1 Effects of CAM pretreatment on the GSH/GSSG ratio in $\mathrm{H}_{2} \mathrm{O}_{2}$-stimulated SAECs. GSH and GSSG were determined using the DTNB recycling method. Samples were obtained from supernatants of control cells, of cells stimulated with $100 \mu \mathrm{M} \mathrm{H} \mathrm{H}_{2}$ alone, or of cells pretreated with 1, 5 or $10 \mu \mathrm{M}$ CAM for $72 \mathrm{~h}$ before stimulation with $100 \mu \mathrm{M} \mathrm{H}_{2} \mathrm{O}_{2}$ for $2 \mathrm{~h}$. Data are presented as means \pm SD of three to four independent experiments. ${ }^{* *} p<0.01$ vs. control cells, ${ }^{\# \#} p<0.01$ vs. cells stimulated with $\mathrm{H}_{2} \mathrm{O}_{2}$ alone, ${ }^{++} p<0.01$ vs. cells pretreated with $10 \mu \mathrm{M}$ CAM

$\mathrm{H}_{2} \mathrm{O}_{2}$-induced CAT and SOD activities between the low- and high-concentration CAM groups $(p<0.05$ or $p<0.01)$.

Effects of CAM pretreatment on $\mathrm{H}_{2} \mathrm{O}_{2}$-induced $\mathrm{HO}-1$ levels and HO-1 mRNA expression in SAECs

Incubation with $\mathrm{H}_{2} \mathrm{O}_{2}$ for $0.5 \mathrm{~h}$ significantly decreased the HO-1 level in SAECs compared to untreated cells $(p<0.01)$. Pretreatment with CAM $(1$ or $5 \mu \mathrm{M})$ for $72 \mathrm{~h}$ had no effect on $\mathrm{HO}-1$ levels in $\mathrm{H}_{2} \mathrm{O}_{2}$-treated cells (Fig. 6a, $p>0.05$ vs. $\mathrm{H}_{2} \mathrm{O}_{2}$ treatment alone). When SAECs were pretreated with $10 \mu \mathrm{M}$ CAM for $72 \mathrm{~h}$, the decrease in HO-1 level induced by treatment with $100 \mu \mathrm{M} \mathrm{H}_{2} \mathrm{O}_{2}$ was rather exacerbated $(p<0.05)$.

HO-1 mRNA expression was also significantly suppressed by $\mathrm{H}_{2} \mathrm{O}_{2}$ treatment $(100 \mu \mathrm{M})$ for $1 \mathrm{~h}$. In contrast to its effects on the $\mathrm{HO}-1$ level, pretreatment with 1 or $5 \mu \mathrm{M}$ CAM, but not with $10 \mu \mathrm{M}$ CAM, for $72 \mathrm{~h}$ significantly increased $\mathrm{HO}-1$ mRNA expression in $\mathrm{H}_{2} \mathrm{O}_{2}$-treated cells compared to $\mathrm{H}_{2} \mathrm{O}_{2}$ treatment alone $(p<0.01)$ (Fig. 6b). As expected, there was a significant difference in HO- 1 mRNA expression in $\mathrm{H}_{2} \mathrm{O}_{2}$-treated cells between the low- and high-concentration CAM groups $(p<0.01)$.

\section{Effects of CAM on $\mathrm{H}_{2} \mathrm{O}_{2}$-induced ERK phosphorylation in SAECS}

The effects of CAM on $\mathrm{H}_{2} \mathrm{O}_{2}$-induced ERK phosphorylation in SAECs were investigated using Western blot analysis. Exposure of SAECs to $\mathrm{H}_{2} \mathrm{O}_{2}(100 \mu \mathrm{M})$ for $0.5 \mathrm{~h}$ significantly increased ERK phosphorylation versus control cells, and this increase in ERK phosphorylation was maintained with treatment of 1 or $5 \mu \mathrm{M}$ CAM for $72 \mathrm{~h}$ before $\mathrm{H}_{2} \mathrm{O}_{2}$ treatment. However, pretreatment with $10 \mu \mathrm{M}$ CAM for $72 \mathrm{~h}$ resulted in a significant decline in $\mathrm{H}_{2} \mathrm{O}_{2}$-induced ERK phosphorylation (Fig. 7, $p<0.01$ vs. $\mathrm{H}_{2} \mathrm{O}_{2}$ treatment alone). As expected, pretreatment with a high concentration $(10 \mu \mathrm{M})$ of CAM for $72 \mathrm{~h}$ also significantly decreased $\mathrm{H}_{2} \mathrm{O}_{2}$-induced ERK phosphorylation compared to pretreatment with a low concentration $(1 \mu \mathrm{M})$ of CAM for $72 \mathrm{~h}(p<0.01)$.

\section{Effects of U0126 pretreatment on the viability of $\mathrm{H}_{2} \mathrm{O}_{2}$-treated cells}

The relationship between suppression of ERK phosphorylation and cell viability was examined using U0126, an ERK inhibitor. When SAECs were treated with U0126 $(10 \mu \mathrm{M})$ or $\mathrm{H}_{2} \mathrm{O}_{2}(100 \mu \mathrm{M})$ for 0.5 or $3 \mathrm{~h}$, respectively, no significant changes in cell viability were observed (Fig. 8). However, in cells pretreated with U0126 before exposure to $\mathrm{H}_{2} \mathrm{O}_{2}$, cell viability was significantly reduced as compared with $\mathrm{H}_{2} \mathrm{O}_{2}$-treatment alone. This indicates that suppression of ERK phosphorylation promotes a decrease in cell viability following $\mathrm{H}_{2} \mathrm{O}_{2}$ treatment.

\section{Discussion}

It is well known that low-dose, long-term macrolide therapy is effective against chronic inflammatory airway diseases [1-5]. As shown in Fig. 1, we previously demonstrated that low-dose (1 or $5 \mu \mathrm{M})$, long-term (72 h) CAM treatment inhibited $\mathrm{H}_{2} \mathrm{O}_{2}$-induced reduction of the GSH/GSSG ratio in SAECs, via the maintenance of GSH levels through an effect on $\gamma$-GCS expression [8]. In contrast to the effect of low-dose CAM, reduction of 


\section{$\square$ : control, $\mathbf{\square}: 100 \mu \mathrm{M} \mathrm{H}_{2} \mathrm{O}_{2}$ alone, $\mathbb{Z}: 100 \mu \mathrm{M} \mathrm{H}_{2} \mathrm{O}_{2}+1 \mu \mathrm{M}$ CAM \\ 曰: $100 \mu \mathrm{M} \mathrm{H}_{2} \mathrm{O}_{2}+5 \mu \mathrm{M}$ CAM, ख: $100 \mu \mathrm{M} \mathrm{H}_{2} \mathrm{O}_{2}+10 \mu \mathrm{M} \mathrm{CAM}$}

\section{a GPx-1}

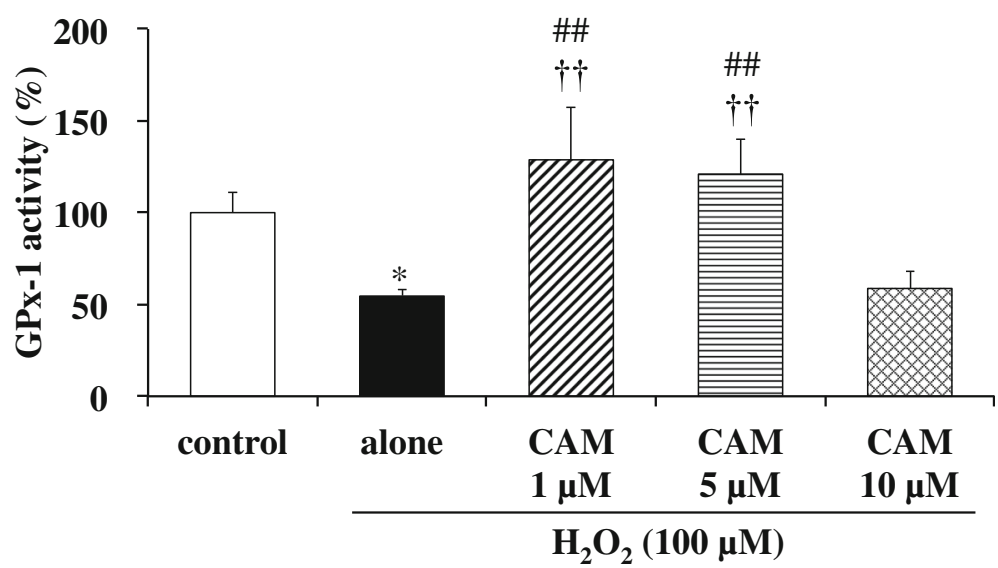

\section{b GPx-1 mRNA}

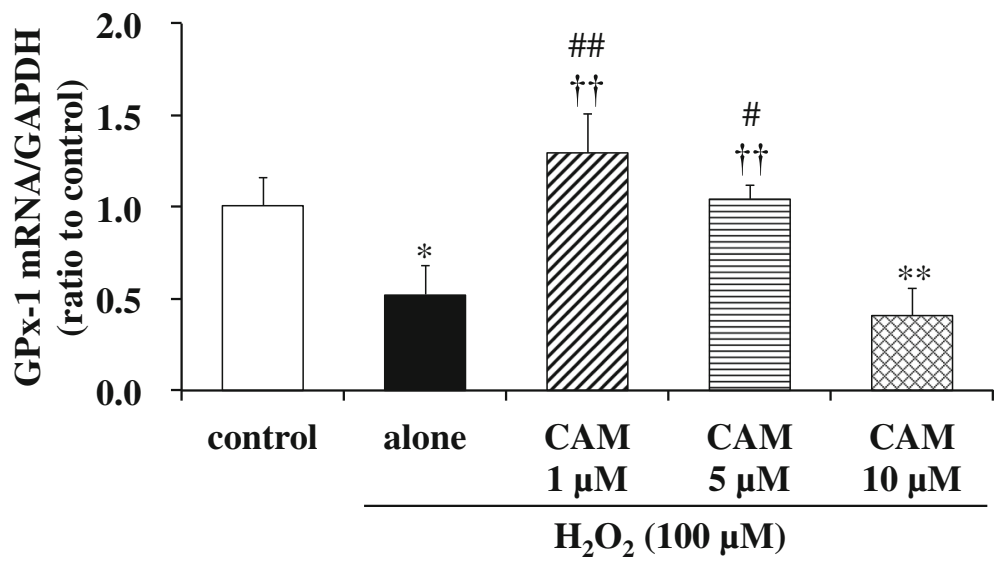

Fig. 2 Effects of CAM pretreatment on GPx-1 activity (a) and mRNA expression (b) in $\mathrm{H}_{2} \mathrm{O}_{2}$-stimulated SAECs. In panel a, GPx-1 activities were measured using the NADPH consumption method. In panel $\mathbf{b}, \mathrm{GPX}-1$ mRNA expression was measured using real-time RT-PCR. Samples were obtained from supernatants (a) or cDNA (b) of control cells, of cells stimulated with $100 \mu \mathrm{M} \mathrm{H}_{2} \mathrm{O}_{2}$ alone, or of cells pretreated with 1,5 or $10 \mu \mathrm{M}$ CAM for $72 \mathrm{~h}$ before stimulation with $100 \mu \mathrm{M} \mathrm{H}_{2} \mathrm{O}_{2}$ for 1.5 or $1 \mathrm{~h}$, respectively. Data are presented as means \pm SD of three independent experiments. ${ }^{*} p<0.05,{ }^{* *} p<0.01$ vs. control cells, ${ }^{\#} p<0.05,{ }^{\# \#} p<0.01$ vs. cells stimulated with $\mathrm{H}_{2} \mathrm{O}_{2}$ alone, ${ }^{+\dagger} p<0.01$ vs. cells pretreated with $10 \mu \mathrm{M}$ CAM

the GSH/GSSG ratio was not prevented by long-term pretreatment of SAECs with a high $(10 \mu \mathrm{M})$ CAM concentration. In general, $\mathrm{H}_{2} \mathrm{O}_{2}$-induced cytotoxicity is thought to be controlled by the ROS scavenging system, including cellular antioxidant enzymes [13], in addition to increasing $\gamma$-GCS expression $[8,22]$. However, the influence of CAM on antioxidant enzyme activities remains unclear. Therefore, in the present study, we first examined the influence of CAM against antioxidant enzymes in SAECs, which are the main cell type involved in chronic airway diseases.

Our study confirmed that CAM inhibited the $\mathrm{H}_{2} \mathrm{O}_{2}$-induced reduction of GPx-1 activity with low-dose treatment, which suppressed the decrease in the GSH/ GSSG ratio, but not with high-dose treatment (Fig. 2a). In addition, this inhibition was associated with increased expression of GPx-1 mRNA, indicating that an increase in GPx-1 activity occurs at the transcriptional level (Fig. 2b). GPx-1 promotes GSH oxidation to the GSSG form, and protects cells from $\mathrm{H}_{2} \mathrm{O}_{2}$-induced cytotoxicity. Furthermore, the lower activity of GR under an oxidative condition favors the accumulation of GSSG in cells. The deficiency of GR is characterized by the sensitivity of membranes to $\mathrm{H}_{2} \mathrm{O}_{2}$ and contributes to oxidative stress, which plays a key role in the pathogenesis of many diseases including chronic airway diseases 


\section{$\square$ : control, $\mathbf{\square}: 100 \mu \mathrm{M} \mathrm{H}_{2} \mathrm{O}_{2}$ alone, $\mathbb{Z}: 100 \mu \mathrm{M} \mathrm{H}_{2} \mathrm{O}_{2}+1 \mu \mathrm{M}$ CAM, \\ 曰: $100 \mu \mathrm{M} \mathrm{H}_{2} \mathrm{O}_{2}+5 \mu \mathrm{M} \mathrm{CAM}, \mathbb{\otimes}: 100 \mu \mathrm{M} \mathrm{H}_{2} \mathrm{O}_{2}+10 \mu \mathrm{M} \mathrm{CAM}$}

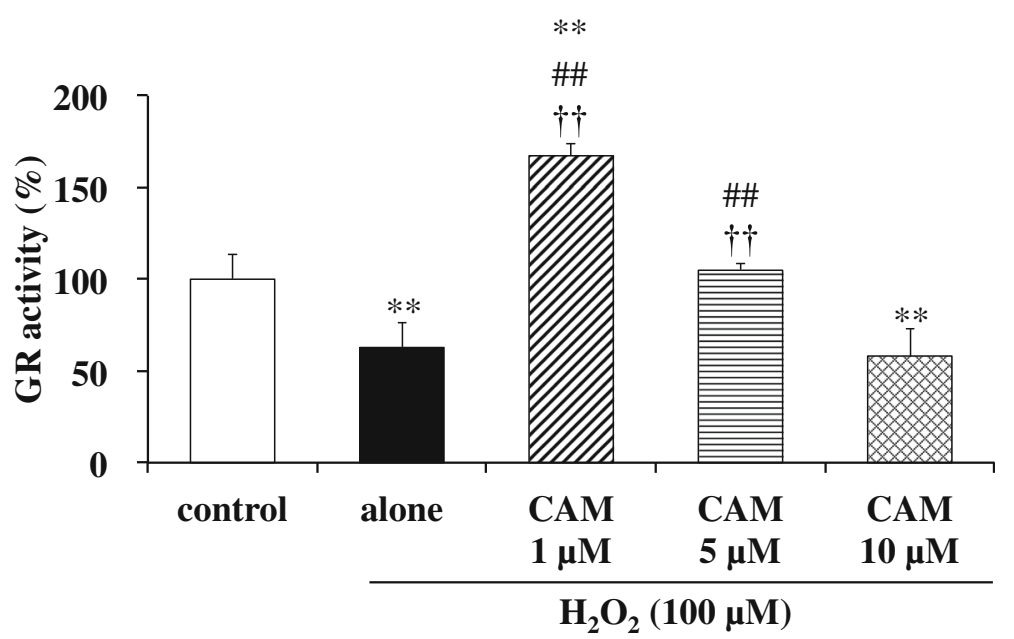

Fig. 3 Effects of CAM pretreatment on GR activity in $\mathrm{H}_{2} \mathrm{O}_{2}$-stimulated SAECs. GR activities were measured using the NADPH consumption method. Samples were obtained from supernatants of control cells, of cells stimulated with $100 \mu \mathrm{M} \mathrm{H} \mathrm{H}_{2}$ alone, or of cells pretreated with 1,5 or $10 \mu \mathrm{M}$ CAM for $72 \mathrm{~h}$ before stimulation with $100 \mu \mathrm{M} \mathrm{H}_{2} \mathrm{O}_{2}$ for $1.5 \mathrm{~h}$. Data are presented as means \pm SD of three to five independent experiments. ${ }^{* *} p<0.01 \mathrm{vs}$. control cells, ${ }^{\# \#} p<0.01$ vs. cells stimulated with $\mathrm{H}_{2} \mathrm{O}_{2}$ alone, ${ }^{\dagger+} p<0.01$ vs. cells pretreated with $10 \mu \mathrm{M}$ CAM

[23]. Pretreatment with a low concentration $(1$ or $5 \mu \mathrm{M})$ of CAM also inhibited the $\mathrm{H}_{2} \mathrm{O}_{2}$-induced reduction of GR activity (Fig. 3); thus, it is suggested that the GSSG produced by GPx-1 was returned to GSH effectively by a recycling reaction involving $\mathrm{GR} . \mathrm{H}_{2} \mathrm{O}_{2}$ reduced CAT activity in a manner that was similar to GPx-1, with CAM pretreatment ameliorating the effects of $\mathrm{H}_{2} \mathrm{O}_{2}$ (Fig. 4). In general, the binding affinity for $\mathrm{H}_{2} \mathrm{O}_{2}$ is considered to be higher in GPx-1 because the Km value of GPx-1 is smaller than that of CAT [24]. Therefore, under the conditions of the present study, it is thought that $\mathrm{GPx}-1$ may exert a greater effect than CAT for $\mathrm{H}_{2} \mathrm{O}_{2}$ elimination in SAECs.

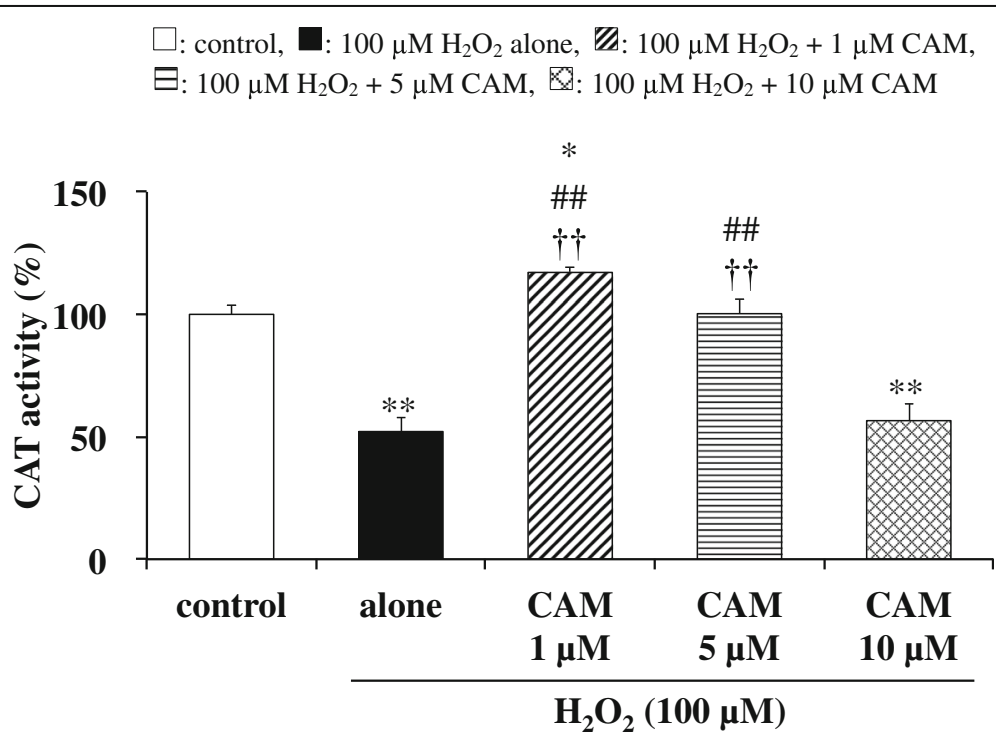

Fig. 4 Effects of CAM pretreatment on CAT activity in $\mathrm{H}_{2} \mathrm{O}_{2}$-stimulated SAECS. CAT activities were measured using a catalase assay kit as

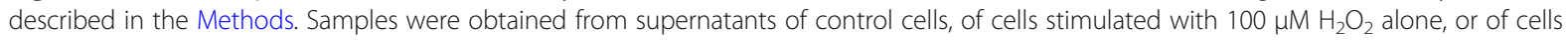
pretreated with 1,5 or $10 \mu \mathrm{M}$ CAM for $72 \mathrm{~h}$ before stimulation with $100 \mu \mathrm{M} \mathrm{H}_{2} \mathrm{O}_{2}$ for $1.5 \mathrm{~h}$. Data are presented as means $\pm \mathrm{SD}$ of three to six independent experiments. ${ }^{*} p<0.05,{ }^{* *} p<0.01$ vs. control cells, ${ }^{\# \#} p<0.01$ vs. cells stimulated with $\mathrm{H}_{2} \mathrm{O}_{2}$ alone, ${ }^{++} p<0.01$ vs. cells pretreated with $10 \mu \mathrm{M}$ CAM 
$\square$ : control, $\mathbf{\square}: 100 \mu \mathrm{M} \mathrm{H}_{2} \mathrm{O}_{2}$ alone, $\mathbb{Z}: 100 \mu \mathrm{M} \mathrm{H}_{2} \mathrm{O}_{2}+1 \mu \mathrm{M} \mathrm{CAM}$,

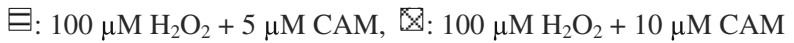

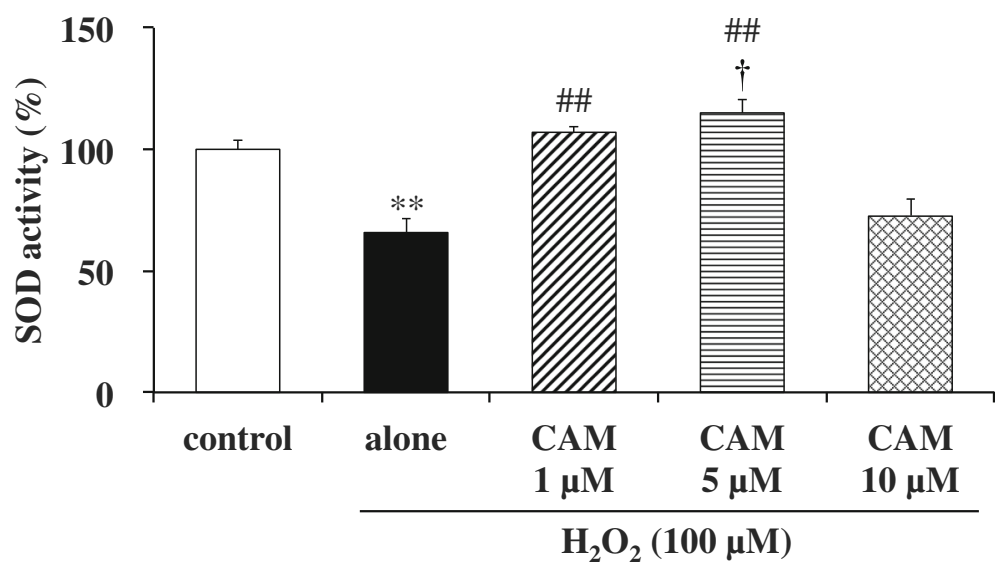

Fig. 5 Effects of CAM pretreatment on SOD activity in $\mathrm{H}_{2} \mathrm{O}_{2}$-stimulated SAECs. SOD activities were assessed by measuring formazan production at $450 \mathrm{~nm}$ as described in the Methods. Samples were obtained from supernatants of control cells, of cells stimulated with $100 \mu \mathrm{M} \mathrm{H} \mathrm{H}_{2} \mathrm{O}_{2}$ alone, or of cells pretreated with 1,5 or $10 \mu \mathrm{M}$ CAM for $72 \mathrm{~h}$ before stimulation with $100 \mu \mathrm{M} \mathrm{H}_{2} \mathrm{O}_{2}$ for $1.5 \mathrm{~h}$. Data are presented as means $\pm \mathrm{SD}$ of three to six independent experiments. ${ }^{* *} p<0.01$ vs. control cells, ${ }^{\# \#} p<0.01$ vs. cells stimulated with $\mathrm{H}_{2} \mathrm{O}_{2}$ alone, ${ }^{\dagger} p<0.05$ vs. cells pretreated with $10 \mu \mathrm{M}$ CAM

That is, the $100 \mu \mathrm{M} \mathrm{H} \mathrm{H}_{2} \mathrm{O}_{2}$ concentration used for inducing cytotoxicity is considered to be low as a substrate of CAT. However, regardless of whether or not CAT is involved in the elimination reaction of $\mathrm{H}_{2} \mathrm{O}_{2}$, it is important that low-dose CAM suppresses the $\mathrm{H}_{2} \mathrm{O}_{2}$-induced decrease in CAT activity. During inflammatory conditions in the lower respiratory tract, neutrophil-derived $\mathrm{H}_{2} \mathrm{O}_{2}$ in the respiratory tract viscous fluid is reported to reach a concentration of $50 \mu \mathrm{M}$ [25]. Since $\mathrm{H}_{2} \mathrm{O}_{2}$ is also produced directly from bronchial epithelial cells following stimulation with pollutants such as bacteria and LPS [26], it is thought that the $\mathrm{H}_{2} \mathrm{O}_{2}$ concentration $(100 \mu \mathrm{M})$ used in this study reflects conditions observed during chronic inflammatory airway diseases. Therefore, it is thought that GPx-1 is mainly involved in the elimination of $\mathrm{H}_{2} \mathrm{O}_{2}$, even in clinical settings. As shown in Figs. 4 and 5, pretreatment with 1 or $5 \mu \mathrm{M}$ CAM for $72 \mathrm{~h}$ showed inducible effects on CAT activity as well as SOD activity, respectively. These results indicate that low-dose CAM promotes an antioxidant effect against oxidative stress in SAECs.

Oxidative stress liberates heme from heme-proteins such as hemoglobin and cytochrome, and HO-1 catalyzes the degradation of heme to produce ferrous iron, carbon monoxide and biliverdin, the latter of which is subsequently converted into bilirubin [27, 28]. Carbon monoxide is involved in the regulation of anti-inflammation [29]. Biliverdin and bilirubin, which can scavenge peroxyl radicals, are potent cytoprotective antioxidants [30]. However, studies have shown that HO-1 overexpression (10 to 15 times the normal amount) increases ROS levels, thereby inducing cell death $[31,32]$. In this study, HO-1 protein levels were significantly decreased by treatment with $\mathrm{H}_{2} \mathrm{O}_{2}$ in SAECs, and CAM failed to elevate the level (Fig. 6a). In contrast, the expression of HO-1 mRNA was significantly increased to the level of control cells by pretreatment with low concentrations ( 1 or $5 \mu \mathrm{M})$ of CAM for $72 \mathrm{~h}$ (Fig. 6b). The change in HO-1 mRNA expression brought about by low CAM concentrations in this study appears to be in the opposite direction to the change in $\mathrm{HO}-1$ protein level. In contrast, another study showed that the addition of $100 \mu \mathrm{M} \mathrm{H} \mathrm{H}_{2} \mathrm{O}_{2}$ alone increased both $\mathrm{HO}-1$ protein and mRNA levels in MC3T3-E1 cells [33]. The differences in HO-1 protein and mRNA levels between the present and previous studies are attributed to differences in the experimental cell type and the $\mathrm{H}_{2} \mathrm{O}_{2}$ treatment time. In regards to the exposure condition of oxidative stress, under our mild oxidative stress condition $\left(\mathrm{H}_{2} \mathrm{O}_{2}\right.$ treatment for 30-60 $\left.\mathrm{min}\right)$, anti-oxidative substances such as $\mathrm{HO}-1$ can function to adjust ROS to normal levels [34]. Therefore, it is suggested that the rate at which $\mathrm{HO}-1$ as an antioxidant removes $\mathrm{H}_{2} \mathrm{O}_{2}$ is faster than that at which low CAM concentrations increases the expression of HO-1 mRNA to normalize HO-1 protein levels. On the other hand, oxidative stress substantially increases the levels of HO-1 and HO-1 mRNA and causes cytotoxicity under a sustained oxidative stress condition of long-term $\mathrm{H}_{2} \mathrm{O}_{2}$ exposure (incubation for 0.514 days) [31-33]. In any case, it was clearly shown that low CAM concentrations induce HO-1 mRNA expression, resulting in protection from oxidative 


\section{$\square$ : control, $\mathbf{\square}: 100 \mu \mathrm{M} \mathrm{H}_{2} \mathrm{O}_{2}$ alone, $\mathbb{Z}: 100 \mu \mathrm{M} \mathrm{H}_{2} \mathrm{O}_{2}+1 \mu \mathrm{M}$ CAM, \\ 曰: $100 \mu \mathrm{M} \mathrm{H}_{2} \mathrm{O}_{2}+5 \mu \mathrm{M}$ CAM, Q: $100 \mu \mathrm{M} \mathrm{H}_{2} \mathrm{O}_{2}+10 \mu \mathrm{M} \mathrm{CAM}$}

\section{a $\mathrm{HO}-1$}

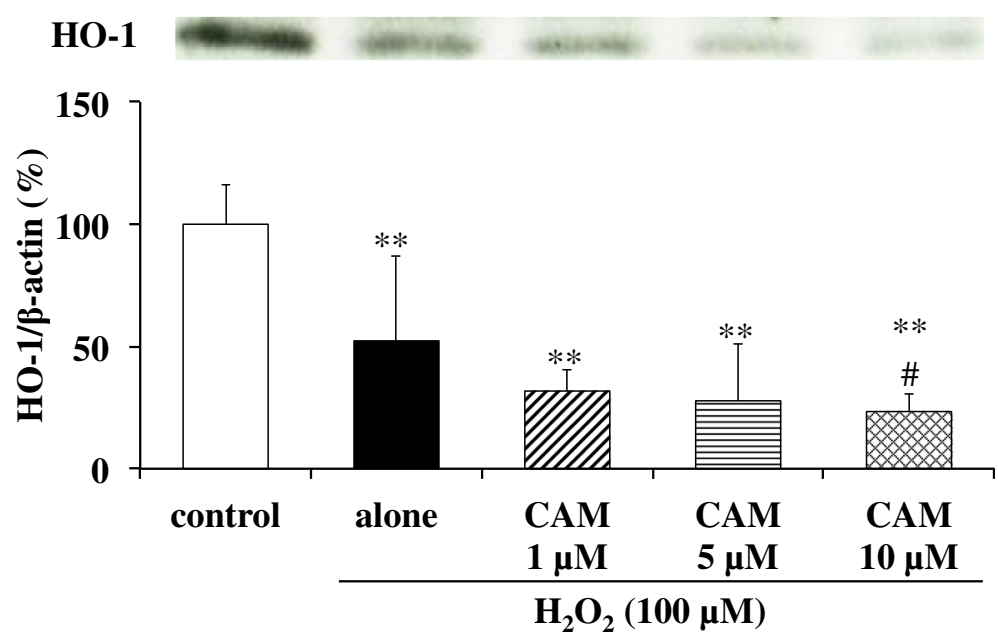

b HO-1 mRNA

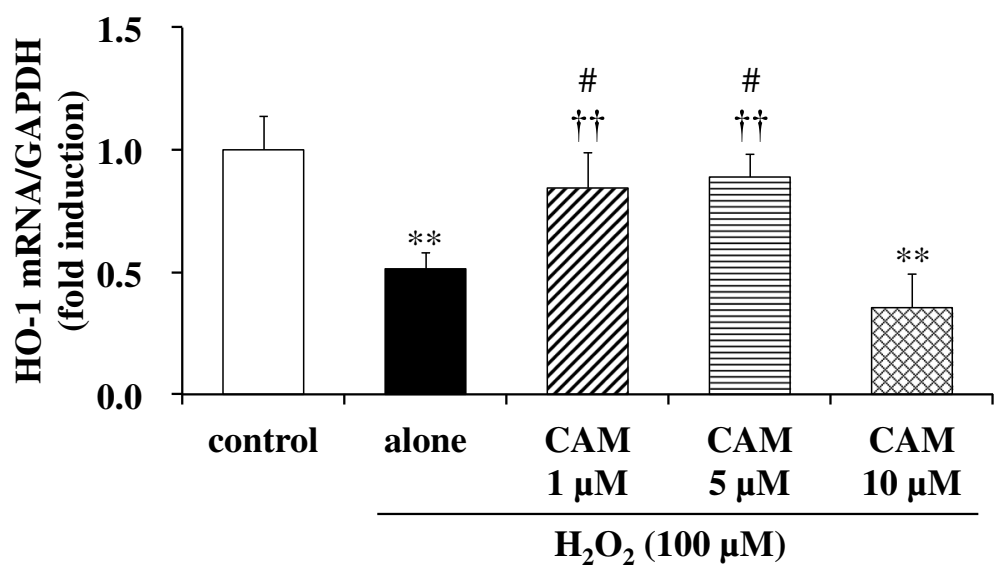

Fig. 6 Effects of CAM pretreatment on HO-1 activation (a) and mRNA expression (b) in $\mathrm{H}_{2} \mathrm{O}_{2}$-stimulated SAECs. In panel a, HO-1 protein levels were detected by Western blotting (upper, representative blot images; lower, quantification of bands). In panel b, HO-1 mRNA expression was measured using real-time RT-PCR. Samples were obtained from cell pellets (a) or cDNA (b) of control cells, of cells stimulated with $100 \mu \mathrm{M} \mathrm{H}_{2} \mathrm{O}_{2}$ alone, or of cells pretreated with 1,5 or $10 \mu \mathrm{M}$ CAM for $72 \mathrm{~h}$ before stimulation with $100 \mu \mathrm{M} \mathrm{H}_{2} \mathrm{O}_{2}$ for 0.5 or $1 \mathrm{~h}$, respectively. The data in panel a are expressed as the $\mathrm{HO}-1 / \beta$-actin ratio. Data are presented as means $\pm \mathrm{SD}$ of three independent experiments. ${ }^{* *} p<0.01 \mathrm{vs}$. control cells, ${ }^{\#} p<0.05$ vs. cells stimulated with $\mathrm{H}_{2} \mathrm{O}_{2}$ alone, ${ }^{\dagger+} p<0.01$ vs. cells pretreated with $10 \mu \mathrm{M}$ CAM

injury. This is a potent benefit that contributes to the anti-inflammatory action of low-dose CAM. In general, an HO-1 inducer such as hemin stimulates the expression of HO-1 mRNA and upregulates $\mathrm{HO}-1$ $[35,36]$. However, in the antioxidant pathway of dimethyl fumarate, another $\mathrm{HO}-1$ inducer, there is a time lag between increases in expression of HO-1 and HO-1 mRNA, and the expression of both is regulated by the concentration and treatment time of dimethyl fumarate [37]. Thus, it is necessary to consider whether other HO-1 inducers show the same effect (including concentration-dependent differences) as low concentrations of CAM. In addition, hydroxyl radical may be generated from $\mathrm{H}_{2} \mathrm{O}_{2}$ by ferrous iron; however, it is thought that biliverdin or bilirubin could function in scavenging hydroxyl radical [30].

In patients with COPD, blood GSH level [38,39] and SOD [40, 41], CAT [42, 43] and GPx-1 [41, 44] activities were significantly reduced compared to healthy subjects. Also, in patients with bronchial asthma, SOD [45] 


\section{$\square$ : control, $\mathbf{\square}: 100 \mu \mathrm{M} \mathrm{H}_{2} \mathrm{O}_{2}$ alone, $\mathbb{Z}: 100 \mu \mathrm{M} \mathrm{H}_{2} \mathrm{O}_{2}+1 \mu \mathrm{M} \mathrm{CAM}$, \\ 曰: $100 \mu \mathrm{M} \mathrm{H}_{2} \mathrm{O}_{2}+5 \mu \mathrm{M} \mathrm{CAM}$, 叉: $100 \mu \mathrm{M} \mathrm{H}_{2} \mathrm{O}_{2}+10 \mu \mathrm{M} \mathrm{CAM}$}

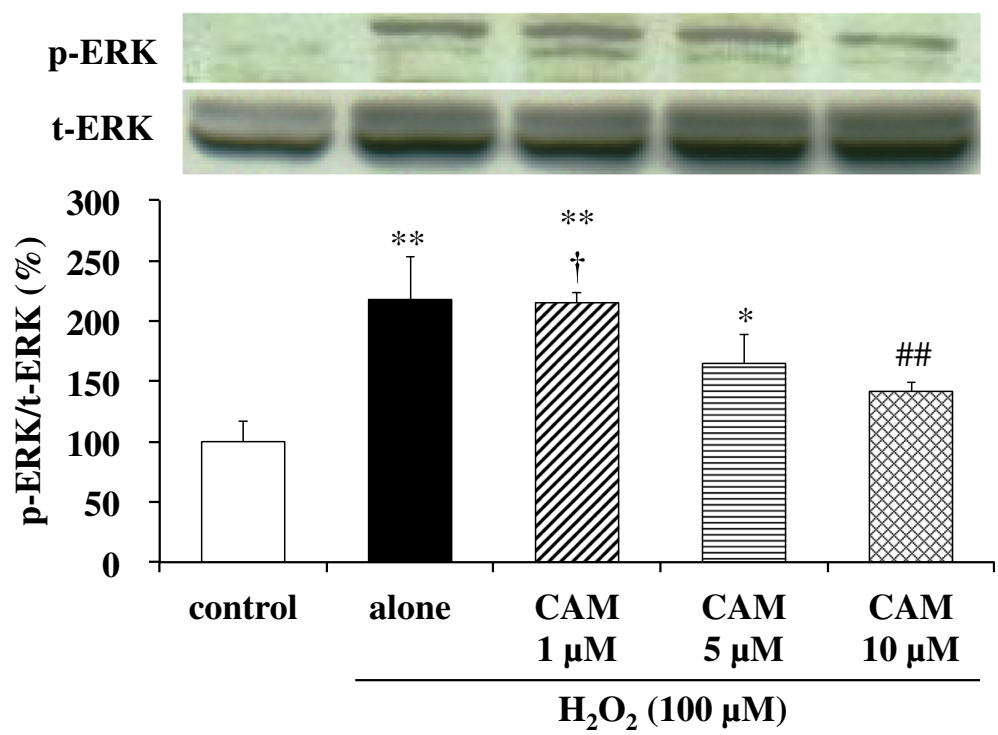

Fig. 7 Effects of CAM pretreatment on p-ERK expression in SAECS stimulated with $\mathrm{H}_{2} \mathrm{O}_{2}$. $\mathrm{p}$-ERK and t-ERK protein levels were detected by Western blotting (upper, representative blot images; lower, quantification of bands). Samples were obtained from cell pellets of control cells, of cells stimulated with $100 \mu \mathrm{M} \mathrm{H}_{2} \mathrm{O}_{2}$ alone, or of cells pretreated with 1, 5, or $10 \mu \mathrm{M}$ CAM for $72 \mathrm{~h}$ before stimulation with $100 \mu \mathrm{M} \mathrm{H} \mathrm{H}_{2} \mathrm{O}_{2}$ for $0.5 \mathrm{~h}$. The data are expressed as the $p$-ERK/t-ERK ratio. Data are presented as means \pm SD of three independent experiments. ${ }^{*} p<0.05,{ }^{* *} p<0.01$ vs. control cells, ${ }^{\# \#} p<0.01$ vs. cells stimulated with $\mathrm{H}_{2} \mathrm{O}_{2}$ alone, ${ }^{\dagger} p<0.05$ vs. cells pretreated with $10 \mu \mathrm{M}$ CAM

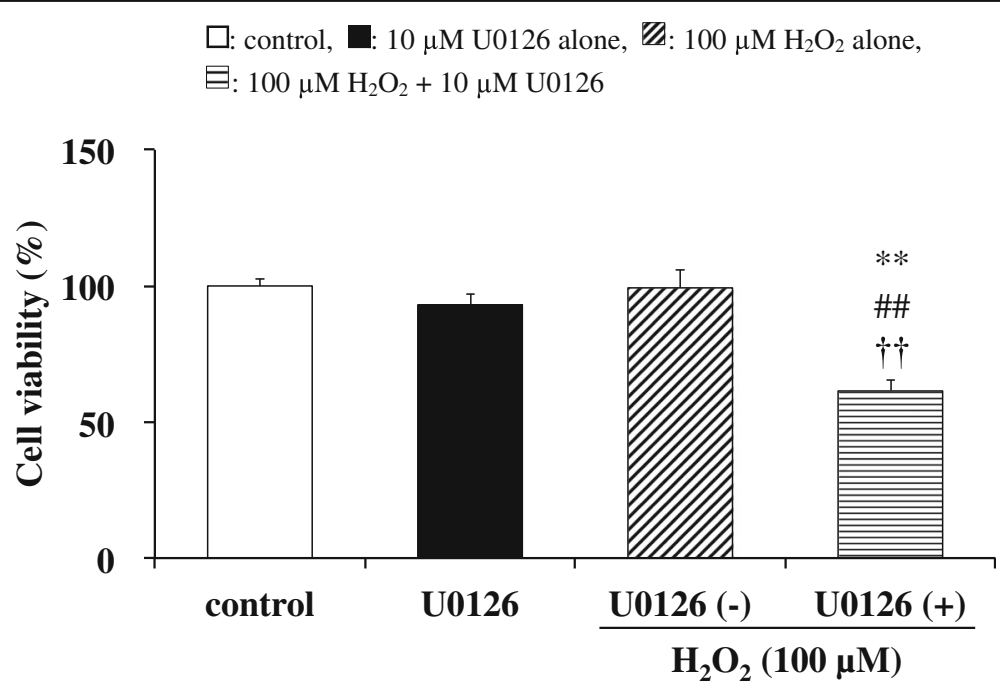

Fig. 8 Effects of $\mathrm{U} 0126$ on cell viability in SAECs stimulated with $\mathrm{H}_{2} \mathrm{O}_{2}$. Cell viability was assessed by measuring formazan production from viable cells (at $450 \mathrm{~nm}$ ) as described in the Methods. Samples were obtained from control cells, from cells pretreated with $10 \mu \mathrm{M}$ U0126 alone for $0.5 \mathrm{~h}$, or from cells pretreated with or without $10 \mu \mathrm{M} \cup 0126$ for $0.5 \mathrm{~h}$ before stimulation with $100 \mu \mathrm{M} \mathrm{H} \mathrm{H}_{2}$ for $3 \mathrm{~h}$. Data are presented as means $\pm \mathrm{SD}$ of three independent experiments. ${ }^{* *} p<0.01$ vs. control cells, ${ }^{\# \#} p<0.01$ vs. cells pretreated with $10 \mu \mathrm{M} \cup 0126$ alone, ${ }^{+t} p<0.01$ vs. cells pretreated without $10 \mu \mathrm{M} \cup 0126$ before $\mathrm{H}_{2} \mathrm{O}_{2}$ stimulation (cells stimulated with $\mathrm{H}_{2} \mathrm{O}_{2}$ alone) 
activity or GPx-1 and GR activities [46] are reported to decrease with decreasing GSH value when exposed to antigens or under symptom deteriorating conditions. Furthermore, it was shown that the GSH level and GPx-1 activity in sputum were decreased in adult patients with cystic fibrosis [47]. These findings strongly suggest that a reduction in antioxidant enzyme activity is involved in the pathogenesis mechanism of chronic inflammatory respiratory diseases [48-50]. Our present study revealed that treatment of SAECs with a low concentration of CAM increased GPx-1, GR, CAT and SOD activities. Moreover, it stimulated the mRNA expressions of GPx-1 and HO-1. It has been reported that all of these cellular antioxidant enzymes and mRNAs are induced via the Nrf2-mediated pathway [51-53]. Nrf2 is a critical transcription factor for protecting cells from oxidative injury. In our previous report, we described that long-term $(72 \mathrm{~h})$ treatment with low concentrations (1 and $5 \mu \mathrm{M}$ ) of CAM activates Nrf2 mRNA expression, inhibiting the $\mathrm{H}_{2} \mathrm{O}_{2}$-induced reduction of the $\mathrm{GSH} /$ GSSG ratio in SAECs through an increase in $\gamma$-GCS expression [8]. These findings suggest that low CAM concentrations reduced oxidative stress in SAECs by inducing the expression and activation of antioxidant protein via Nrf2 signaling, which enhances GSH levels by activating GSH synthesis. The $\alpha, \beta$-unsaturated ketone structure leads to Nrf2 activation and acts as an inducer of antioxidant response element genes [54]. However, CAM does not have a known Nrf2-binding moiety in its chemical structure. To better understand the involvement of $\mathrm{Nrf} 2$ in antioxidant protein expression after treatment with CAM, future studies employing knock-down and inhibitors of Nrf2 are needed.

It was suggested that treatment with low concentrations (1 and $5 \mu \mathrm{M})$ of CAM enhances protective responses by the intracellular $\mathrm{H}_{2} \mathrm{O}_{2}$ elimination system. On the other hand, this effect was not observed in the treatment with high-dose $(10 \mu \mathrm{M}) \mathrm{CAM}$, and cell viability decreased as previously reported [8]. In order to clarify the cause of decreased cell viability by high CAM concentration, the effect of CAM on the phosphorylation of ERK, which is a MAP kinase pathway involved in cell proliferation, was investigated. Treatment of SAECs with low CAM concentrations for $72 \mathrm{~h}$ did not show any significant change in ERK phosphorylation. However, the phosphorylation was significantly decreased by treatment with high-dose CAM, indicating the possibility that cell proliferation was suppressed (Fig. 7). However, the relationship between inhibition of cell proliferation and decrease in cell viability has been unclear. Therefore, the effect on cell viability was examined using U0126, an ERK inhibitor [55]. When $\mathrm{U} 0126$ and $\mathrm{H}_{2} \mathrm{O}_{2}$ were used in combination, a strong decrease in cell viability was induced (Fig. 8). Therefore, it was revealed that suppression of cell proliferation is largely involved in the reduction of cell viability. The mode of cell death by long-term treatment with high-dose CAM can be considered as either apoptosis or necrosis. In SAECs, treatment with $\mathrm{H}_{2} \mathrm{O}_{2}(75 \mu \mathrm{M})$ has been reported to induce apoptosis [56]. However, we observed that CAM had no effects on caspase-3 activity and mitochondrial membrane potential in SAECs (see Additional files 5 and 6). Furthermore, it was previously shown that $72 \mathrm{~h}$ pretreatment with $10 \mu \mathrm{M}$ CAM maintained $\mathrm{H}_{2} \mathrm{O}_{2}$-induced NF- $\mathrm{KB}$ activation in SAECs [8]. Therefore, there is a high possibility that anti-apoptotic factors are produced via NF- $\mathrm{B}$ activation [57, 58], thereby enabling necrosis [59]. Also, as reported in the previous study [8], the levels of intracellular CAM gradually changed over time and did not plateau until after $72 \mathrm{~h}$ incubation of the cells with CAM. The results showed that cells incubated with $10 \mu \mathrm{M}$ CAM did not reach concentrations of more than twice that of cells incubated with $5 \mu \mathrm{M}$ CAM; however, significantly higher intracellular CAM concentrations were observed. Since EM has been found to exacerbate the oxidant/antioxidant balance in cells when its concentration in the extracellular fluid exceeds $6.8 \mu \mathrm{M}$ [60], it is possible that the same changes occur in cells during pretreatment with $10 \mu \mathrm{M}$ CAM, via an unknown mechanism. Necrosis induced by the suppression of ERK phosphorylation might be involved in this mechanism.

There is no evidence to indicate whether the exposure of cells to CAM for $72 \mathrm{~h}$ can be a model for the effect of long-term administration of CAM in the clinical setting. Furthermore, it is difficult to predict its effects in clinical settings based on its observed effects on cells. Nevertheless, low-dose, long-term clinical administration of CAM is thought to enhance anti-oxidative defense reactions during periods of oxidative stress.

\section{Conclusions}

This study showed that pretreatment of SAECs with low-dose, long-term CAM resulted in increased activities of GPx-1, GR, SOD, CAT, HO-1 and mRNA expressions of $\mathrm{GPx}-1$ and $\mathrm{HO}-1$ after treatment with $\mathrm{H}_{2} \mathrm{O}_{2}$. Activation of transcription factor $\mathrm{Nrf} 2$ by low-dose CAM may be involved in the increased activity of these antioxidant enzymes. On the other hand, pretreatment with high-dose CAM suppressed the phosphorylation of ERK involved in cell proliferation, resulting in decreased cell viability. These data indicate that CAM is efficacious against oxidative stress-induced cell dysfunction under low-dose, long-term treatment conditions. Although it is not possible to directly translate pharmacological effects on cells into therapeutic 
effects in clinical practice, consistent with the previous report [8], the present study presents evidence as to why low-dose, long-term macrolide therapy is effective against chronic inflammatory airway diseases.

\section{Additional files}

Additional file 1: Effects of CAM pretreatment on IL-8 protein and mRNA levels in $\mathrm{H}_{2} \mathrm{O}_{2}$-stimulated SAECs. (PDF $118 \mathrm{~kb}$ )

Additional file 2: Effects of CAM on cell viability in SAECs stimulated with $\mathrm{H}_{2} \mathrm{O}_{2}$. (PDF $82 \mathrm{~kb}$ )

Additional file 3: Effects of CAM on cell viability in SAECs. (PDF $61 \mathrm{~kb}$ )

Additional file 4: Effects of $\mathrm{H}_{2} \mathrm{O}_{2}$ on cell viability in SAECs. (PDF $70 \mathrm{~kb}$ )

Additional file 5: Caspase-3 activation induced by $\mathrm{H}_{2} \mathrm{O}_{2}$ after CAM pretreatment in SAECs. (PDF $74 \mathrm{~kb}$ )

Additional file 6: Mitochondrial membrane potential induced by $\mathrm{H}_{2} \mathrm{O}_{2}$ after CAM pretreatment in SAECs. (PDF $73 \mathrm{~kb}$ )

\begin{abstract}
Abbreviations
ANOVA: One-way analysis of variance; CAM: Clarithromycin; CAT: Catalase; COPD: Chronic obstructive pulmonary disease; DMSO: Dimethyl sulfoxide; DPBS: Dulbecco's phosphate-buffered saline; DTNB: 5,5'-Dithiobis(2nitrobenzoic acid); EDTA: Ethylenediaminetetraacetic acid; EM: Erythromycin; ERK: Extracellular signal regulatory kinase; GAPDH: Glyceraldehyde-3phosphate dehydrogenase; GPx: Glutathione peroxidase; GR: Glutathione reductase; GSH: Glutathione; GSSG: Oxidized glutathione; $\mathrm{H}_{2} \mathrm{O}_{2}$ : Hydrogen peroxide; HO: Heme oxygenase; IL: Interleukin; JNK: c-jun N-terminal kinase; Km: Michaelis constant; LPS: Lipopolysaccharide; MAPK: Mitogen activated protein kinase; NADPH: Reduced nicotinamide adenine dinucleotide phosphate; NBT: Nitrobluetetrazolium; Nrf2: Nuclear factor erythroid 2-related factor 2; PBS: Phosphate-buffered saline; PCR: Polymerase chain reaction; $\mathrm{p}$ ERK: Phosphorylated ERK; ROS: Reactive oxygen species; SABM: Small airway basal medium; SAEC: Human small airway epithelial cell; SAGM: Small airway growth medium; SOD: Superoxide dismutase; WST-8: 2-(2-Methoxy-4nitrophenyl)-3-(4-nitrophenyl)-5-(2,4-disulfophenyl)-2H-tetrazolium; Y-GCS: YGlutamylcysteine synthetase
\end{abstract}

\section{Funding}

All of the funds for this study were provided by Hokkaido Pharmaceutical University. The funding body played a role in the design of the study, in the collection and analysis of data, and in the writing of the manuscript.

\section{Availability of data and materials}

The datasets supporting the conclusions of this article are included within the article and its additional files.

\section{Authors' contributions}

$\mathrm{NH}$ and $\mathrm{KI}$ designed the research. $\mathrm{Kl}, \mathrm{JK}, \mathrm{AM}$ and AK performed the experiments, and analyzed data. $\mathrm{Kl}, \mathrm{JK}, \mathrm{KO}, \mathrm{YT}$ and $\mathrm{NH}$ participated in interpretation of the results. $\mathrm{Kl}$ drafted the manuscript, and $\mathrm{NH}$ revised the manuscript and provided an editorial review. All authors read and approved the final manuscript.

\section{Ethics approval and consent to participate}

Not applicable.

\section{Consent for publication}

Not applicable.

\section{Competing interests}

The authors declare that they have no competing interests. Furthermore, the funding body has no competing interests in the interpretation of the present results.

\section{Publisher's Note}

Springer Nature remains neutral with regard to jurisdictional claims in published maps and institutional affiliations.

\section{Author details}

'Department of Pharmacology and Therapeutics, Hokkaido Pharmaceutical University School of Pharmacy, 7-15-4-1 Maeda, Teine, Sapporo, Hokkaido 006-8590, Japan. ${ }^{2}$ Department of Hospital Pharmacy and Pharmacology, Asahikawa Medical University Hospital, Asahikawa 078-8510, Japan. ${ }^{3}$ Department of Pharmacy, Nakamura Memorial Hospital, Sapporo 060-8570, Japan. ${ }^{4}$ Department of Pharmacy, Kushiro Kojinkai Memorial Hospital, Kushiro 085-0062, Japan. ${ }^{5}$ Department of Pharmacy, Shin-Sapporo Towakai Hospital, Sapporo 004-0041, Japan. ${ }^{6}$ Department of Public and Health, Hokkaido Pharmaceutical University School of Pharmacy, Sapporo 006-8590, Japan.

Received: 30 January 2018 Accepted: 4 July 2018

Published online: 03 September 2018

\section{References}

1. Kudoh S, Azuma A, Yamamoto M, Izumi T, Ando M. Improvement of survival in patients with diffuse panbronchiolitis treated with low-dose erythromycin. Am J Respir Crit Care Med. 1998;157:1829-32.

2. Seemungal TA, Wilkinson TM, Hurst JR, Perera WR, Sapsford RJ, Wedzicha JA Long-term erythromycin therapy is associated with decreased chronic obstructive pulmonary disease exacerbations. Am J Respir Crit Care Med. 2008:178:1139-47.

3. Kostadima E, Tsiodras S, Alexopoulos El, Kaditis AG, Mavrou I, Georgatou N, et al. Clarithromycin reduces the severity of bronchial hyperresponsiveness in patients with asthma. Eur Respir J. 2004:23:714-7.

4. Pukhalsky AL, Shmarina GV, Kapranov NI, Kokarovtseva SN, Pukhalskaya D, Kashirskaja NJ. Anti-inflammatory and immunomodulating effects of clarithromycin in patients with cystic fibrosis lung disease. Mediat Inflamm. 2004;13:111-7.

5. Gotfried MH. Macrolides for the treatment of chronic sinusitis, asthma, and COPD. Chest. 2004;125:52S-60S.

6. Khair OA, Devalia JL, Abdelaziz MM, Sapsford RJ, Davies RJ. Effect of erythromycin on Haemophilus influenzae endotoxin-induced release of IL-6, IL-8 and sICAM-1 by cultured human bronchial epithelial cells. Eur Respir J. 1995:8:1451-7.

7. Aoshiba K, Nagai A, Konno K. Erythromycin shortens neutrophil survival by accelerating apoptosis. Antimicrob Agents Chemother. 1995:39:872-7.

8. Iwayama K, Kusakabe A, Ohtsu K, Nawano T, Tatsunami R, Ohtaki K, Tampo $Y$, Hayase N. Long-term treatment of clarithromycin at low-concentration improves hydrogen peroxide-induced oxidant/antioxidant imbalance in human small airway epithelial cells by increasing Nrf2 mRNA expression. BMC Pharmacol Toxicol. 2017:18:15.

9. Kostikas K, Papatheodorou G, Psathakis K, Panagou P, Loukides S. Oxidative stress in expired breath condensate of patients with COPD. Chest. 2003:124:1373-80

10. Emelyanov A, Fedoseev G, Abulimity A, Rudinski K, Fedoulov A, Karabanov A, Barnes PJ. Elevated concentrations of exhaled hydrogen peroxide in asthmatic patients. Chest. 2001:120:1136-9.

11. Loukides S, Horvath I, Wodehouse T, Cole PJ, Barnes PJ. Elevated levels of expired breath hydrogen peroxide in bronchiectasis. Am J Respir Crit Care Med. 1998:158:991-4.

12. Psathakis K, Mermigkis D, Papatheodorou G, Loukides S, Panagou P, Polychronopoulos V, Siafakas NM, Bouros D. Exhaled markers of oxidative stress in idiopathic pulmonary fibrosis. Eur J Clin Investig. 2006;36:362-7.

13. Long $H$, Ting $H$, Shabnam $F$, Linbao J, Tianyi L, Xi M. Antioxidants maintain cellular redox homeostasis by elimination of reactive oxygen species. Cell Physiol Biochem. 2017:44:532-53.

14. Maria L, Martina H, Klaus-Peter Z, Ernesto G, Sven H, Rudolf L, Trinad C, Helena P. Pneumococcal hydrogen peroxide-induced stress signaling regulates inflammatory genes. JID. 2015;211:306-16.

15. Yang D, Jin M, Bai C, Zhou J, Shen Y. Peroxiredoxin 6 suppresses Muc5ac overproduction in LPS-induced airway inflammation through $\mathrm{H}_{2} \mathrm{O}_{2}$-EGFRMAPK signaling pathway. Respir Physiol Neurobiol. 2017;236:84-90.

16. Pelaia G, Cuda G, Vatrella A, Gallelli L, Fratto D, Gioffrè V, D'Agostino B, Caputi M, Maselli R, Rossi F, Costanzo FS, Marsico SA. Effects of hydrogen peroxide on MAPK activation, IL-8 production and cell viability in primary cultures of human bronchial epithelial cells. J Cell Biochem. 2004;93:142-52. 
17. Wang J, Huang J, Wang L, Chen C, Yang D, Jin M, Bai C, Song Y. Urban particulate matter triggers lung inflammation via the ROS-MAPK-NF-KB signaling pathway. J Thorac Dis. 2017:9:4398-412.

18. Chen SJ, Zhang W, Tong Q, Conrad K, Hirschler-Laszkiewicz I, Bayerl M, Kim JK, Cheung JY, Miller BA. Role of TRPM2 in cell proliferation and susceptibility to oxidative stress. Am J Physiol Cell Physiol. 2013;304:C548-60.

19. Zhang H, Newman DR, Sannes PL. HSULF-1 inhibits ERK and AKT signaling and decreases cell viability in vitro in human lung epithelial cells. Respir Res. 2012;13:69.

20. Parthasarathy S, Barnett J, Fong LG. High-density lipoprotein inhibits the oxidative modification of low-density lipoprotein. Biochim Biophys Acta. 1990;1044:275-83.

21. Tsukamoto M, Tampo Y, Sawada M, Yonaha M. Paraquat-induced oxidative stress and dysfunction of the glutathione redox cycle in pulmonary microvascular endothelial cells. Toxicol Appl Pharmacol. 2002;178:82-92.

22. Katsuyama Y, Tsuboi T, Taira N, Yoshioka M, Masaki H. 3-O-Laurylglyceryl ascorbate activates the intracellular antioxidant system through the contribution of PPAR-y and Nrf2. J Dermatol Sci. 2016;82:189-96.

23. Ulusu NN, Tandoğan B. Purification and kinetic properties of glutathione reductase from bovine liver. Mol Cell Biochem. 2007 Sep;303(1-2):45-51.

24. Antunes F, Han D, Cadenas E. Relative contributions of heart mitochondria glutathione peroxidase and catalase to $\mathrm{H}(2) \mathrm{O}(2)$ detoxification in in vivo conditions. Free Radic Biol Med. 2002;33:1260-7.

25. Kikuchi E, Yamazaki K, Kikuchi J, Hasegawa N, Hashimoto S, Ishizaka A, et al. Pharmacokinetics of clarithromycin in bronchial epithelial lining fluid. Respirology. 2008;13:221-6.

26. Test ST, Weiss SJ. Quantitative and temporal characterization of the extracellular $\mathrm{H}_{2} \mathrm{O}_{2}$ pool generated by human neutrophils. J Biol Chem. 1984 Jan;259:399-405.

27. Takahashi T, Morita K, Akagi R, Sassa S. Heme oxygenase-1: a novel therapeutic target in oxidative tissue injuries. Curr Med Chem. 2004;11: 1545-61.

28. Takahashi T, Morita K, Akagi R, Sassa S. Defense against oxidative tissue injury: the essential role played by heme oxygenase-1. Curr Enzym Inhib. 2006;2:105-24.

29. Ryter SW, Choi AM. Heme oxygenase-1/carbon monoxide: from metabolism to molecular therapy. Am J Respir Cell Mol Biol. 2009;41:251-60.

30. Kapitulnik J. Bilirubin: an endogenous product of heme degradation with both cytotoxic and cytoprotective properties. Mol Pharmacol. 2004;66:773-9.

31. Suttner DM, Dennery PA. Reversal of HO-1 related cytoprotection with increased expression is due to reactive iron. FASEB J. 1999;13:1800-9.

32. Bansal S, Biswas G, Avadhani NG. Mitochondria-targeted heme oxygenase-1 induces oxidative stress and mitochondrial dysfunction in macrophages, kidney fibroblasts and in chronic alcohol hepato-toxicity. Redox Biol. 2014:2:273-83

33. Lee $\mathrm{D}$, Kook SH, Ji H, Lee SA, Choi KC, Lee KY, Lee JC. N-acetyl cysteine inhibits $\mathrm{H}_{2} \mathrm{O}_{2}$-mediated reduction in the mineralization of MC3T3-E1 cells by down-regulating Nrf2/HO-1 pathway. BMB Rep. 2015;48:636-41.

34. Kim KA, Kook SH, Song JH, Lee JC. A phenolic acid phenethyl urea derivative protects against irradiation-induced osteoblast damage by modulating intracellular redox state. J Cell Biochem. 2014;115:1877-87.

35. Ahanger AA, Prawez S, Leo MD, Kathirvel K, Kumar D, Tandan SK, Malik JK. Pro-healing potential of hemin: an inducer of heme oxygenase-1. Eur J Pharmacol. 2010;645:165-70.

36. Ferrándiz ML, Devesa I. Inducers of heme oxygenase-1. Curr Pharm Des. 2008;14:473-86.

37. Kasarełło K, Jesion A, Tyszkowska K, Matusik K, Czarzasta K, Wrzesień R Cudnoch-Jedrzejewska A. Effect of dimethyl fumarate on heme oxygenase-1 expression in experimental allergic encephalomyelitis in rats. Folia Neuropathol. 2017;55:325-32.

38. Vibhuti A, Arif E, Mishra A, Deepak D, Singh B, Rahman I, Mohammad G, Pasha MA. CYP1A1, CYP1A2 and CYBA gene polymorphisms associated with oxidative stress in COPD. Clin Chim Acta. 2010;411:474-80.

39. ben Anes A, Fetoui $\mathrm{H}$, Bchir $\mathrm{S}$, ben Nasr H, Chahdoura H, Chabchoub E, Yacoub S, Garrouch A, Benzarti M, Tabka Z, Chahed K. Increased oxidative stress and altered levels of nitric oxide and peroxynitrite in Tunisian patients with chronic obstructive pulmonary disease: correlation with disease severity and airflow obstruction. Biol Trace Elem Res. 2014;161:20-31.

40. Stanojkovic I, Kotur-Stevuljevic J, Milenkovic B, Spasic S, Vujic T, Stefanovic A, Llic A, Ivanisevic J. Pulmonary function, oxidative stress and inflammatory markers in severe COPD exacerbation. Respir Med. 2011;105:S31-7.
41. Zeng M, Li Y, Jiang Y, Lu G, Huang X, Guan K. Local and systemic oxidative stress status in chronic obstructive pulmonary disease patients. Can Respir J. 2013;20:35-41.

42. Ahmad A, Shameem M, Husain Q. Altered oxidant-antioxidant levels in the disease prognosis of chronic obstructive pulmonary disease. Int J Tuberc Lung Dis. 2013;17:1104-9.

43. Tavilani H, Nadi E, Karimi J, Goodarzi MT. Oxidative stress in COPD patients, smokers, and non-smokers. Respir Care. 2012;57:2090-4.

44. Vibhuti A, Arif E, Deepak D, Singh B, Qadar Pasha MA. Correlation of oxidative status with BMI and lung function in COPD. Clin Biochem. 2007:40:958-63.

45. Comhair SA, Bhathena PR, Dweik RA, Kavuru M, Erzurum SC. Rapid loss of superoxide dismutase activity during antigen-induced asthmatic response. Lancet. 2000;355(9204):624.

46. Gumral N, Naziroglu M, Ongel K, Beydilli ED, Ozguner F, Sutcu R, Caliskan S, Akkaya A. Antioxidant enzymes and melatonin levels in patients with bronchial asthma and chronic obstructive pulmonary disease during stable and exacerbation periods. Cell Biochem Funct. 2009;27:276-83.

47. Dauletbaev N, Viel K, Buhl R, Wagner TO, Bargon J. Glutathione and glutathione peroxidase in sputum samples of adult patients with cystic fibrosis. J Cyst Fibros. 2004;3:119-24.

48. McGuinness AJ, Sapey E. Oxidative stress in COPD: sources, markers, and potential mechanisms. J Clin Med. 2017;6:21. https://doi.org/10.3390/ jcm6020021.

49. Zinellu E, Zinellu A, Fois AG, Carru C, Pirina P. Circulating biomarkers of oxidative stress in chronic obstructive pulmonary disease: a systematic review. Respir Res. 2016;17:150.

50. Liguori I, Russo G, Curcio F, Bulli G, Aran L, Della-Morte D, Gargiulo G, Testa G, Cacciatore F, Bonaduce D, Abete P. Oxidative stress, aging, and diseases. Clin Interv Aging. 2018;13:757-72.

51. Kalyanaraman B. Teaching the basics of redox biology to medical and graduate students: oxidants, antioxidants and disease mechanisms. Redox Biol. 2013:1:244-57.

52. Vincent AM, Kato K, McLean LL, Soules ME, Feldman EL. Sensory neurons and Schwann cells respond to oxidative stress by increasing antioxidant defense mechanisms. Antioxid Redox Signal. 2009;11:425-38.

53. Kim HJ, Vaziri ND. Contribution of impaired Nrf2-Keap1 pathway to oxidative stress and inflammation in chronic renal failure. Am J Physiol Renal Physiol. 2010;298:F662-71.

54. Magesh S, Chen Y, Hu L. Small molecule modulators of Keap1-Nrf2-ARE pathway as potential preventive and therapeutic agents. Med Res Rev. 2012;32:687-726.

55. Petecchia L, Sabatini F, Varesio L, Camoirano A, Usai C, Pezzolo A, Rossi GA. Bronchial airway epithelial cell damage following exposure to cigarette smoke includes disassembly of tight junction components mediated by the extracellular signal-regulated kinase 1/2 pathway. Chest. 2009;135:1502-12.

56. Okada M, Sugita K, Inukai T, Goi K, Kagami K, Kawasaki K, Nakazawa S. Hepatocyte growth factor protects small airway epithelial cells from apoptosis induced by tumor necrosis factor-alpha or oxidative stress. Pediatr Res. 2004:56:336-44.

57. Shindo K, lizuka M, Sasaki K, Konno S, Itou H, Horie Y, Watanabe S. Sucralfate prevents the delay of wound repair in intestinal epithelial cells by hydrogen peroxide through NF-kappaB pathway. J Gastroenterol. 2006;41:450-61.

58. Kaltschmidt B, Kaltschmidt C, Hofmann TG, Hehner SP, Dröge W, Schmitz $\mathrm{ML}$. The pro- or anti-apoptotic function of NF-kappaB is determined by the nature of the apoptotic stimulus. Eur J Biochem. 2000;267:3828-35.

59. Bai L, Chen W, Wang X, Ju W, Xu S, Lin Y. Attenuating Smac mimetic compound 3-induced NF-kappaB activation by luteolin leads to synergistic cytotoxicity in cancer cells. J Cell Biochem. 2009;108:1125-31.

60. He Z, Li B, Yu L, Liu Q, Zhong N, Ran P. Suppression of oxidant-induced glutathione synthesis by erythromycin in human bronchial epithelial cells. Respiration. 2008;75:202-9. 